\title{
Quality Assessment of Groundwater for Agriculture in the Hail Region, Saudi Arabia
}

\author{
Abdulaziz B. Alharbi ${ }^{1}$
}

\begin{abstract}
As a result of the arid climate of Saudi Arabia, groundwater is the most precious natural resource, providing reliable water supply for the resident population and the development of irrigated agriculture where surface water resources are insufficient and little to meet the water budget requirements of the Kingdom of Saudi Arabia. Therefore, this study was carried out to evaluate the quality of groundwater resources in selected locations of Hail region. This study focused on the important chemical analysis of the available groundwater resources in Hail region. Groundwater samples were collected from 61wells at different locations that cover the Hail region for chemical analysis. Parameters such as pH, electrical conductivity (EC), sodium (Na), potassium (K), calcium (Ca), magnesium ( $\mathrm{Mg})$, carbonate $\left(\mathrm{CO}_{3}^{--}\right)$bicarbonate $\left(\mathrm{HCO}_{3}^{-}\right)$, chloride $\left(\mathrm{Cl}^{-}\right)$, and heavy metals were analyzed moreover the calculation of sodium adsorption ratio (SAR) to assess the suitability of groundwater for agricultural purposes. The $\mathrm{pH}$ values were between 7.10 and $8.23(\mathrm{M}=$ 7.66). The salinity of groundwater, as a primary indicator of water quality for irrigation, ranged between moderate and high (between 0.27 to $8.99 \mathrm{dS} \mathrm{m}^{-1}$ ) in most studied water samples. Besides salinity, $31.1 \%$ of Hail groundwater samples have the potential risk of chloride hazard (chloride $>10 \mathrm{meq}^{-1}$ ). SAR values were less than 9 for all groundwater samples while the heavy metals were within acceptable levels.
\end{abstract}

Key words: Groundwater, water quality, salinity, heavy metals.

\section{INTRODUCTION}

The Kingdom of Saudi Arabia, known as one of the countries with the highest water scarcity in the world, depends mostly on groundwater as the main water source due to its limited surface water resources and average annual rainfall of less than $100 \mathrm{~mm}$ (Al-Omran, 2002).. The quality of groundwater is a major constraint against the development of irrigated agriculture (Oster and Jayawardane, 1998). In other words, Kumaresan and Riyazuddin (2006) reported that the chemical and physical parameters of groundwater play an important role in assessing water quality. Salts affect the yield as well as the suitability of the soil for growth of plant. The suitability of particular irrigation water is highly

\footnotetext{
DOI: 10.21608/ASEJAIQJSAE.2020.115129

${ }^{1}$ Plant Production and Protection Department, College of Agriculture \&

Veterinary Medicine, Qassim University, Buraydah, KSA.

Email: aabanialharby@hotmail.com

Received August 26, 2020, Accepted, September 22, 2020.
}

dependent on the actual need and economic return that can be obtained from salt water irrigation compared to other options, as well as the limited conditions of use. Important conditions of use include the crop being grown, cropping management practices, various soil properties and management practices, irrigation, climatic changes. Moreover, salinization of groundwater due to overuse, increased population growth rate, high water loss by evaporation, limited recharge, and the overlap between seawater-freshwater (Sheikhy Narany et al., 2014). A study of the acidic and alkaline properties for water, gives an indication of the extent water interaction with different materials (Hem, 1985). Ayers and Westcot (1985) reported that the greatest direct hazard of water with an abnormal $\mathrm{pH}$, is the impact on irrigation equipment. So, it is necessary to choose irrigation equipment properly, when handling water of unusual $\mathrm{pH}$. An adverse $\mathrm{pH}$ may need to be corrected by the introduction of chemical substances into the water.

In some environments, increased $\left(\mathrm{Cl}^{-}\right)$ concentrations have killed off the native vegetation and allowed invasive salt-tolerant species to thrive (Panno et al., 1999). Chloride can damage plants from excessive foliar absorption (sprinkler systems) or excessive root uptake (drip irrigation). The concentration of ion chloride restriction $\left(\mathrm{Cl}^{-}\right)$in irrigation water with lower than $4 \mathrm{meq} \mathrm{L}^{-1}$ is considered light, while it is moderate between 4 and $10 \mathrm{meq} \mathrm{L}^{-1}$, and higher than $10 \mathrm{meq} \mathrm{L}^{-}$ ${ }^{1}$ are considered severe. The maximum limit is 30 meq L ${ }^{-1}$ (Palacios et al., 1997).

The concentration of carbonates in natural waters is a function of the amount of dissolved carbon dioxide, temperature, $\mathrm{pH}$, cations and other dissolved salts. The concentration of bicarbonate in natural waters is generally held within a moderate range by the effects of the carbonate equilibrium (Kumar et al., 2017).

Groundwater is the major resources for irrigation in most of the Hail region, where used deep wells water from the Saq Aquifer, which forms one of the major aquifers and extends for $1200 \mathrm{~km}$ approximately, in the northwest-southeast direction, in Northwestern Saudi Arabia (Hereher et al., 2012). 
The Saq Aquifer it is confined or leaky in deeper layers but is unconfined in shallow layers. Except a few areas, Saq Aquifer has very good water quality. (Sharaf and Hussein, 1996). The values of TDS are ranged between $300-1000 \mathrm{mg} \mathrm{L}^{-1}$. The Saq groundwater is classified into different water types, the most dominant are $\mathrm{Ca}\left(\mathrm{HCO}_{3}\right)_{2}$ or $\mathrm{NaHCO}_{3}$ and $\mathrm{NaCI}$ types (Alawi and Abdulrazzak, 1993; Mohammed et al., 2011). Sharaf and Hussein (1996) and Abdel-Aal et al. (1997) reported that the groundwater of Saudi Arabia is deteriorating at an alarming rate due to the increasing water salinity. Its electrical conductivity has increased from $1.93 \mathrm{dS} \mathrm{m}^{-1}$ in 1983 to $2.76 \mathrm{dS} \mathrm{m}^{-1}$ in 1997 in the Saq Aquifer; if this depletion continues unabated, the agricultural land may not be able to survive. Consequently, the assessment of the quality of such limited water resources has become an imperative tool for managing these resources in the best possible manner for any future sustainable development.

In the present study, the objective was to evaluate the quality of groundwater for irrigation in the Hail region.

\section{MATERIALS AND METHODS}

\section{Study area:}

Hail is a city in north-western Saudi Arabia. It is largely agricultural, with significant grain, date, and fruit production. A large percentage of the kingdom's wheat production comes from the Hail region. It has a continental desert climate with hot summers and cool winters. As a result of its higher altitude, it has a somewhat milder climate than other Saudi cities.

\section{Sampling sites}

In this study, water samples were collected from 61wells at different locations that cover the Hail region (Map. 1). And the GPS was used to record the absolute positions of collected samples as shown in Table 1. The water samples were analyzed in the Department of Plant Production and Protection, College of Agriculture and Veterinary Medicine, Qassim University, Buriydah, Saudi Arabia.

Water samples were transported immediately to the laboratory in ice boxes and chemical analyses were carried out to assess the water quality, Map 1. Location of the studied areas.

\section{Water quality measurements}

The $\mathrm{pH}, \mathrm{EC}$, soluble ions, and heavy metals were determined as follows:
The $\mathrm{pH}$ was determined using a $\mathrm{pH}$ meter $(\mathrm{pH}$ meter -Jenway 3310).

The total soluble salts were measured by using an electrical conductivity meter (EC) in $\mathrm{dSm}^{-1}$ at $25^{\circ} \mathrm{C}$ (Jenway 4310).

Chloride concentration was measured by Mohr's titration method. Total alkalinity, Calcium and Magnesium were measured by the titration methods (Jackson, 1967)

The soluble potassium and sodium were determined using a flame photometer apparatus (PFP7, Jenway LTD, Felsted, England). The heavy metals ( $\mathrm{Zn}, \mathrm{Cu}, \mathrm{Ni}$ and $\mathrm{Pb}$ ) were determined using ICP, ThermoModel7000.

Water quality evaluation for irrigation in Hail was conducted according the criteria of (Ayers and Westcot, 1985) and U.S. salinity laboratory (Richard, 1954).

\section{RESULTS AND DISCUSSION}

\section{Water pH}

The $\mathrm{pH}$ of water is an indicator of its acidity or basicity, but it rarely constitutes a problem by itself. The main use of $\mathrm{pH}$ in water analysis is for the detection of abnormal water. The normal $\mathrm{pH}$ range for irrigation water is from 6.5 to 8.4. An abnormal value is a warning that the water requires further evaluation. Irrigation water with a $\mathrm{pH}$ outside the normal range may cause a nutritional imbalance or may contain a toxic ion (Ayers and Westcot, 1985). The water $\mathrm{pH}$ values for the study area are presented in Table 2. The maximum $\mathrm{pH}$ value was 8.23 while the minimum was $7.10,(\mathrm{M}=7.66)$. The lowest $\mathrm{pH}$ value was found in location 3 while the highest value was found in location L5. It was found that the $\mathrm{pH}$ of water was in the normal range $6.5-8.4$ (Ayers and Westcot, 1985).

\section{Water salinity}

The salinity of water was presented as EC values $\left(\mathrm{dS} \mathrm{m}{ }^{-1}\right)$. Highly saline irrigation water reduces osmotic potential of the soil solution, plant available water, seed germination, rooting, growth, establishment, and fruiting of plants (Duncan et al., 2009, Hillel, 2000).

Table 2 shows the irrigation water salinity (EC) of Hail farms (study area). There are a wide variations among the salinity levels in different samples. The results showed that the EC values ranged from 0.27 to $8.99 \mathrm{dS} \mathrm{m}^{-1}$ in the study area. The lowest value was found in location 5, while the highest was in location 4 . 
Table 1. Sampling location of the study area.

\begin{tabular}{|c|c|c|c|c|c|}
\hline Location & Altitude & Location & Altitude & Location & Altitude \\
\hline \multirow[t]{2}{*}{$* \mathrm{~L} 1 * * \mathrm{P} 1$} & N27 1929.1 & L2P6 & N27 03158 & L3P6 & N28 02383 \\
\hline & E43 1455.0 & & E42 50480 & & E41 55372 \\
\hline \multirow[t]{2}{*}{ L1P2 } & N27 2048.6 & L2P7 & N27 06189 & L3P7 & N28 01585 \\
\hline & E43 1442.8 & & E42 46175 & & E42 02212 \\
\hline \multirow[t]{2}{*}{ L1P3 } & N27 2229.1 & L2P8 & N27 07209 & L3P8 & N27 55523 \\
\hline & E43 1502.8 & & E42 47446 & & E41 50191 \\
\hline \multirow[t]{2}{*}{ L1P4 } & N27 2640 & L2P9 & N27 09077 & L3P9 & N27 53041 \\
\hline & E43 1823.6 & & E42 42459 & & E41 48245 \\
\hline \multirow[t]{2}{*}{ L1P5 } & N27 2582.9 & L2P10 & N27 13276 & L3P10 & N27 51287 \\
\hline & E43 1937.8 & & E42 38124 & & E41 42430 \\
\hline \multirow[t]{2}{*}{ L1P6 } & N27 280.1 .9 & L2P11 & N27 13120 & L3P11 & N27 51189 \\
\hline & E43 2535.3 & & E42 43181 & & E41 38017 \\
\hline \multirow[t]{2}{*}{ L1P7 } & N27 3429.9 & $\mathrm{~L} 2 \mathrm{P} 12$ & N27 15407 & L3P12 & N27 49133 \\
\hline & E43 2314.3 & & E42 39487 & & E41 34087 \\
\hline \multirow[t]{2}{*}{ L1P8 } & N27 3636.6 & $\mathrm{~L} 2 \mathrm{P} 13$ & N27 16153 & L4P1 & N27 51375 \\
\hline & E43 1148.3 & & E42 44153 & & E42 00017 \\
\hline \multirow[t]{2}{*}{ L1P9 } & $\mathrm{N} 274043$ & L2P14 & N27 16043 & $\mathrm{~L} 4 \mathrm{P} 2$ & N27 06035 \\
\hline & E43 0634.5 & & E42 58203 & & E 4200017 \\
\hline \multirow[t]{2}{*}{ L1P10 } & N27 2317.8 & L2P15 & N27 10568 & L4P3 & N27 59577 \\
\hline & E43 0221.2 & & E42 59038 & & E42 12063 \\
\hline \multirow[t]{2}{*}{ L1P11 } & N27 1925.7 & L2P16 & N27 12044 & L5P1 & N27 48194 \\
\hline & E43 0630.4 & & E4307 404 & & E42 33502 \\
\hline \multirow[t]{2}{*}{ L1P12 } & N27 1633.2 & L2P17 & N27 11299 & L5P2 & N27 47181 \\
\hline & E43 0537.3 & & E43 05546 & & E42 34345 \\
\hline \multirow[t]{2}{*}{ L1P13 } & N27 2119.8 & L2P18 & N27 13470 & L5P3 & $\mathrm{N} 2743039$ \\
\hline & E43 0032.3 & & E43 04324 & & E42 34246 \\
\hline \multirow[t]{2}{*}{ L1P14 } & N27 1823.5 & L2P19 & N27 15596 & L5P4 & N27 40555 \\
\hline & E43 0128.3 & & E43 13596 & & E42 32205 \\
\hline \multirow[t]{2}{*}{ L1P15 } & N27 1735.7 & $\mathrm{~L} 2 \mathrm{P} 20$ & N27 14438 & L5P5 & N27 37215 \\
\hline & $431224.9 \mathrm{E}$ & & E43 06492 & & E42 36050 \\
\hline \multirow[t]{2}{*}{ L1P16 } & N27 1618.9 & $\mathrm{~L} 2 \mathrm{P} 21$ & N27 16101 & L5P6 & N27 35170 \\
\hline & E43 1412.5 & & E43 14115 & & E42 37577 \\
\hline \multirow[t]{2}{*}{ L2P1 } & N27 15383 & L3P1 & N27 58045 & L5P7 & N27 32116 \\
\hline & E43 21262 & & E41 38426 & & E42 33470 \\
\hline \multirow[t]{2}{*}{ L2P2 } & N27 0643.9 & L3P2 & N27 59017 & L5P8 & N27 29049 \\
\hline & E43 02542 & & E41 40193 & & E42 29524 \\
\hline \multirow[t]{2}{*}{ L2P3 } & N27 07235 & L3P3 & N27 59103 & L5P9 & N27 24560 \\
\hline & E43 00508 & & E041 41566 & & E42 241001 \\
\hline \multirow[t]{2}{*}{ L2P4 } & N27 07342 & L3P4 & N28 00580 & & \\
\hline & E43 00418 & & E41 43405 & & \\
\hline \multirow[t]{2}{*}{ L2P5 } & N27 01355 & L3P5 & N28 00551 & & \\
\hline & E42 50046 & & E41 48508 & & \\
\hline
\end{tabular}

$* \mathrm{~L}=$ location, $* * \mathrm{P}=$ position of well 


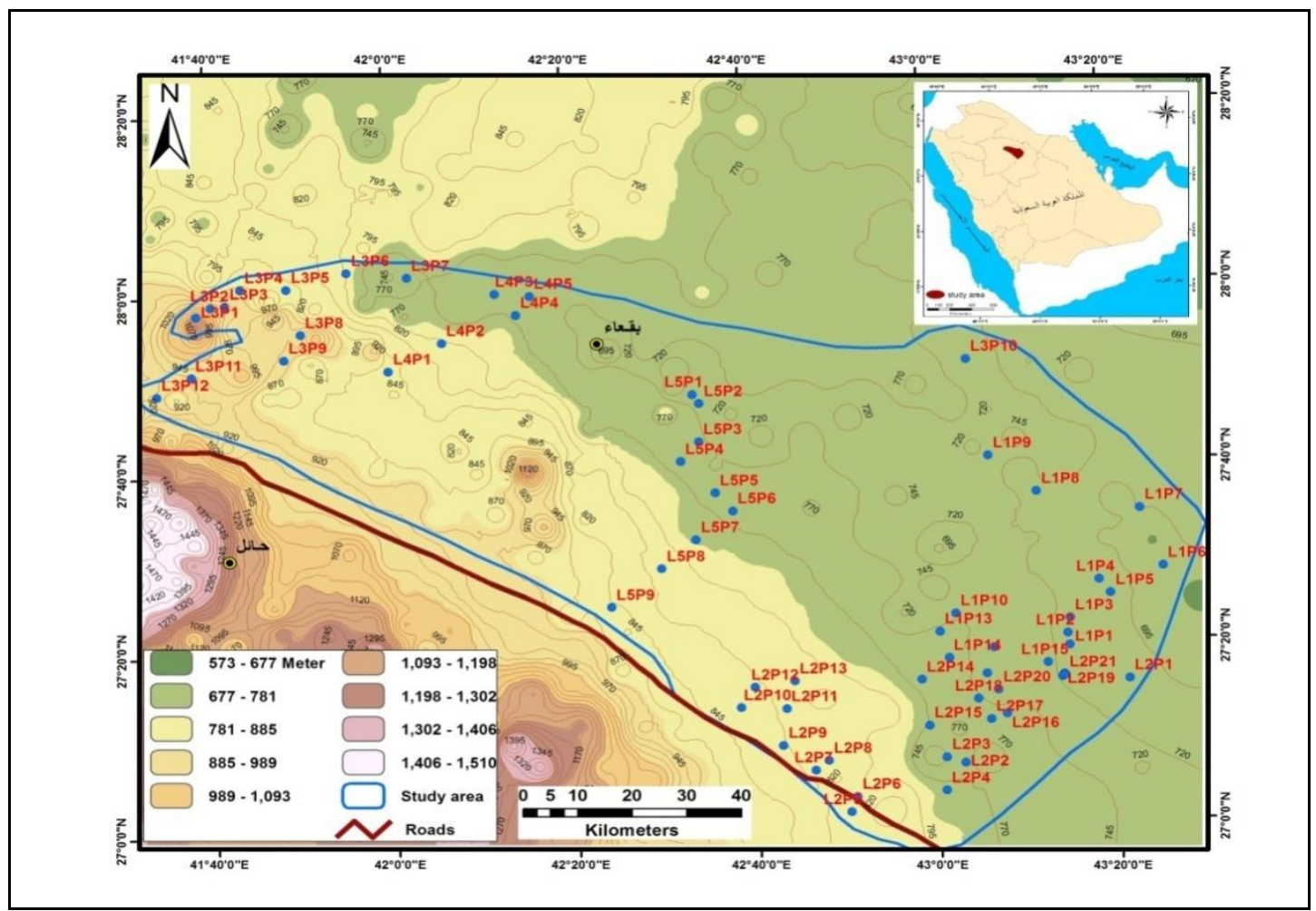

Map 1. The map of the study area was prepared using Arc GIS 9.3 software.

Table 2. Descriptive statistics of the chemical properties of water from Hail region.

\begin{tabular}{|c|c|c|c|c|c|c|c|c|c|c|c|}
\hline L. & & $\mathbf{p H}$ & $\begin{array}{c}E C \\
d_{S} \mathbf{m}^{-1} \\
\end{array}$ & $\begin{array}{c}\mathrm{Na} \\
\mathrm{meq} / \mathrm{L}\end{array}$ & $\begin{array}{c}\mathrm{Ca} \\
\mathrm{meq} / \mathrm{L}\end{array}$ & $\begin{array}{c}\mathrm{Mg} \\
\mathrm{meq} / \mathrm{L}\end{array}$ & $\begin{array}{c}\mathrm{K} \backslash \\
\mathrm{meq} / \mathrm{L}\end{array}$ & $\begin{array}{l}\mathrm{HCO}_{3}^{-} \\
\mathrm{meq} / \mathrm{L}\end{array}$ & $\begin{array}{c}\text { alkalinity } \\
\mathrm{mg} / \mathrm{L}\end{array}$ & $\begin{array}{c}\mathrm{Cl} \\
\mathrm{meq} / \mathrm{L}\end{array}$ & SAR \\
\hline \multirow[t]{3}{*}{ L1 } & Mini. & 7.12 & 0.55 & 3.14 & 1.02 & 1.01 & 0.15 & 1.02 & 51 & 2.03 & 2.93 \\
\hline & Maxi. & 8.11 & 3.66 & 15.8 & 17.2 & 5.55 & 0.56 & 2.23 & 111 & 14.0 & 4.68 \\
\hline & M- SD & $\begin{array}{l}7.78- \\
0.83\end{array}$ & $\begin{array}{l}1.18- \\
0.26\end{array}$ & $\begin{array}{c}6.52- \\
3.57\end{array}$ & $\begin{array}{c}4.08- \\
3.99\end{array}$ & $\begin{array}{l}1.99- \\
1.35\end{array}$ & $\begin{array}{c}0.33- \\
0.15\end{array}$ & $\begin{array}{l}1.44- \\
0.43\end{array}$ & $72-21.5$ & $\begin{array}{l}5.74- \\
3.82\end{array}$ & $\begin{array}{l}4.62- \\
2.275\end{array}$ \\
\hline \multirow[t]{3}{*}{ L2 } & Mini. & 7.53 & 0.69 & 3.43 & 2.18 & 0.52 & 0.12 & 1.1 & 55 & 4.1 & 2.54 \\
\hline & Maxi. & 7.94 & 3.57 & 18.4 & 9.91 & 10.9 & 0.53 & 2.54 & 127 & 25.2 & 5.71 \\
\hline & M- SD & $\begin{array}{l}7.77- \\
0.114\end{array}$ & $\begin{array}{l}1.74- \\
0.97\end{array}$ & $\begin{array}{l}8.72- \\
4.32\end{array}$ & $\begin{array}{l}5.41- \\
2.66\end{array}$ & $\begin{array}{l}4.16- \\
3.26\end{array}$ & $\begin{array}{c}0.21- \\
0.1\end{array}$ & $\begin{array}{l}1.68- \\
0.45\end{array}$ & $82-22.5$ & $\begin{array}{l}11.6- \\
7.07\end{array}$ & $\begin{array}{l}4.0- \\
3.34\end{array}$ \\
\hline \multirow[t]{3}{*}{ L3 } & Mini. & 7.10 & 0.89 & 4.03 & 3.08 & 1.35 & 0.11 & 1.13 & 56.5 & 4.02 & 2.72 \\
\hline & Maxi. & 7.63 & 5.94 & 25.2 & 20.3 & 17.7 & 0.28 & 2.13 & 106 & 34.0 & 5.79 \\
\hline & M- SD & $\begin{array}{l}7.42- \\
0.194\end{array}$ & $1.91-1.4$ & $\begin{array}{c}9.59- \\
5.66\end{array}$ & $\begin{array}{l}6.3- \\
4.71\end{array}$ & $\begin{array}{c}4.61- \\
4.58\end{array}$ & $\begin{array}{l}0.16- \\
0.05\end{array}$ & $\begin{array}{l}1.76- \\
0.36\end{array}$ & $88-18$ & $\begin{array}{l}10.0- \\
8.19\end{array}$ & $\begin{array}{l}4.11- \\
2.63\end{array}$ \\
\hline \multirow[t]{3}{*}{ L4 } & Mini. & 7.55 & 1.24 & 6.65 & 3.4 & 3.3 & 0.12 & 1.08 & 54 & 4.85 & 3.63 \\
\hline & Maxi. & 7.66 & 8.99 & 50.9 & 26.6 & 23.5 & 1.48 & 2.34 & 117 & 48.5 & 10.1 \\
\hline & M- SD & $\begin{array}{l}7.59- \\
0.056\end{array}$ & $\begin{array}{l}5.67- \\
3.99\end{array}$ & $\begin{array}{l}31.7- \\
22.7\end{array}$ & $\begin{array}{c}16.8- \\
12.0\end{array}$ & $\begin{array}{c}16.7- \\
11.6\end{array}$ & $\begin{array}{c}0.93- \\
0.71\end{array}$ & $\begin{array}{l}1.88- \\
0.69\end{array}$ & $94-34.5$ & $\begin{array}{l}29.3- \\
22.3\end{array}$ & $\begin{array}{r}7.75- \\
6.61\end{array}$ \\
\hline \multirow[t]{3}{*}{ L5 } & Mini. & 7.72 & 0.27 & 0.74 & 0.39 & 0.11 & 0.05 & 0.03 & 1.5 & 0.65 & 1.48 \\
\hline & Maxi. & 8.23 & 6.8 & 38.6 & 20.0 & 22.2 & 0.76 & 1.98 & 99 & 40.3 & 8.40 \\
\hline & M- SD & $\begin{array}{l}7.68- \\
0.147\end{array}$ & $\begin{array}{l}1.77- \\
2.04 \\
\end{array}$ & $\begin{array}{l}9.2- \\
9.87\end{array}$ & $\begin{array}{l}5.6- \\
5.73 \\
\end{array}$ & $\begin{array}{l}4.6- \\
6.87 \\
\end{array}$ & $\begin{array}{c}0.18- \\
0.22 \\
\end{array}$ & $\begin{array}{c}1.04- \\
0.53 \\
\end{array}$ & $52-26.5$ & $\begin{array}{c}9.13- \\
12.2 \\
\end{array}$ & $\begin{array}{c}4.08- \\
3.9\end{array}$ \\
\hline
\end{tabular}

L: Location, Mini: Minimum, Maxi: Maximum, M-SD: Mean-Standard Deviation. 
Figure 1 shows that there are no water samples with a salinity concentration of less than $0.25 \mathrm{dSm}^{-1}$, which can be classified according to the US Department of Agriculture (Richard, 1954) to Low Salinity Water (C1). The results also indicated that $18.7 \%$ of water samples with salinity ranged between 0.25 and 0.75 $\mathrm{dSm}^{-1}$, can be classified according to the US Department of Agriculture (Richard, 1954) to (C2) moderate Salinity Water.

It is also clear that $52.5 \%$ of saline water samples are located between 0.75 and $2.25 \mathrm{dSm}^{-1}$, which can be classified as high salinity water (C3) and $28.8 \%$ of water samples have salinity concentration greater than $2.25 \mathrm{dSm}^{-1}$, which can be classified as very high salinity water (C4) according to the US Department of Agriculture (Richard, 1954). This water is not suitable for irrigation under normal conditions, but it can be used under specific conditions, such as high permeability and good drainage conditions. Ayers and Westcot (1985) reported that the salinity of water is greater than $3 \mathrm{dSm}^{-1}$ becomes difficultly for using it in irrigation systems.

However, throughout the world under widely different conditions of soil, irrigation, yields and climate, waters of many different compositions ranging in salinity up to at least $6000 \mathrm{mg} / \mathrm{l}$ TDS $\left(8 \mathrm{dSm}^{-1}\right)$ are being used productively for irrigation in numerous places (Rhoades et al., 1992).

The results depicted in Figure 1, exhibited higher values of water salinity in location 2 compared to other locations. This represents a very rapid and severe water quality deterioration in location 2 . This is due to the continuous agricultural expansion and development in this part compared to other locations and the increased demands on water supplies, which is manifested in more groundwater abstraction and deterioration.

\section{Cations}

In Hail groundwater, the major cations' abundance order is $\mathrm{K}^{+}<\mathrm{Mg}^{2+}<\mathrm{Ca}^{2+}<\mathrm{Na}^{+}$, where the main composition of groundwater is highly affected by the lithology of rocks rather than human activities (Toumi et al., 2015).

The calcium ion concentrations ranged between 0.39 and 26.6meq $\mathrm{L}^{-1}$ (Table 2). Ingram(2014) and Will and Faust(1999) reported that calcium levels below $40 \mathrm{mg} / \mathrm{L}$ will typically need fertilizers containing calcium to prevent deficiency while high levels of calcium above $100 \mathrm{mg} / \mathrm{L}$ may lead to antagonism and result in the deficiency of phosphorus and or magnesium. High levels of calcium may also lead to clogged irrigation equipment due to scale formation $\left(\mathrm{CaCO}_{3}\right.$ and other compounds precipitating out of solution). Consequently, $9.83 \%$ of farms require fertilization with calcium.

The magnesium ion concentrations ranged from 0.11-23.5meq L ${ }^{-1}$ (Table 2). Ingram (2014) and Will and Faust(1999) reported that like calcium, magnesium in water tends to originate from the rock and generally only causes problems when it is below $25 \mathrm{mg} / \mathrm{L}$, necessitating the addition of a magnesium fertilizer. Consequently, there are $47.5 \%$ of farms which require fertilization with magnesium.

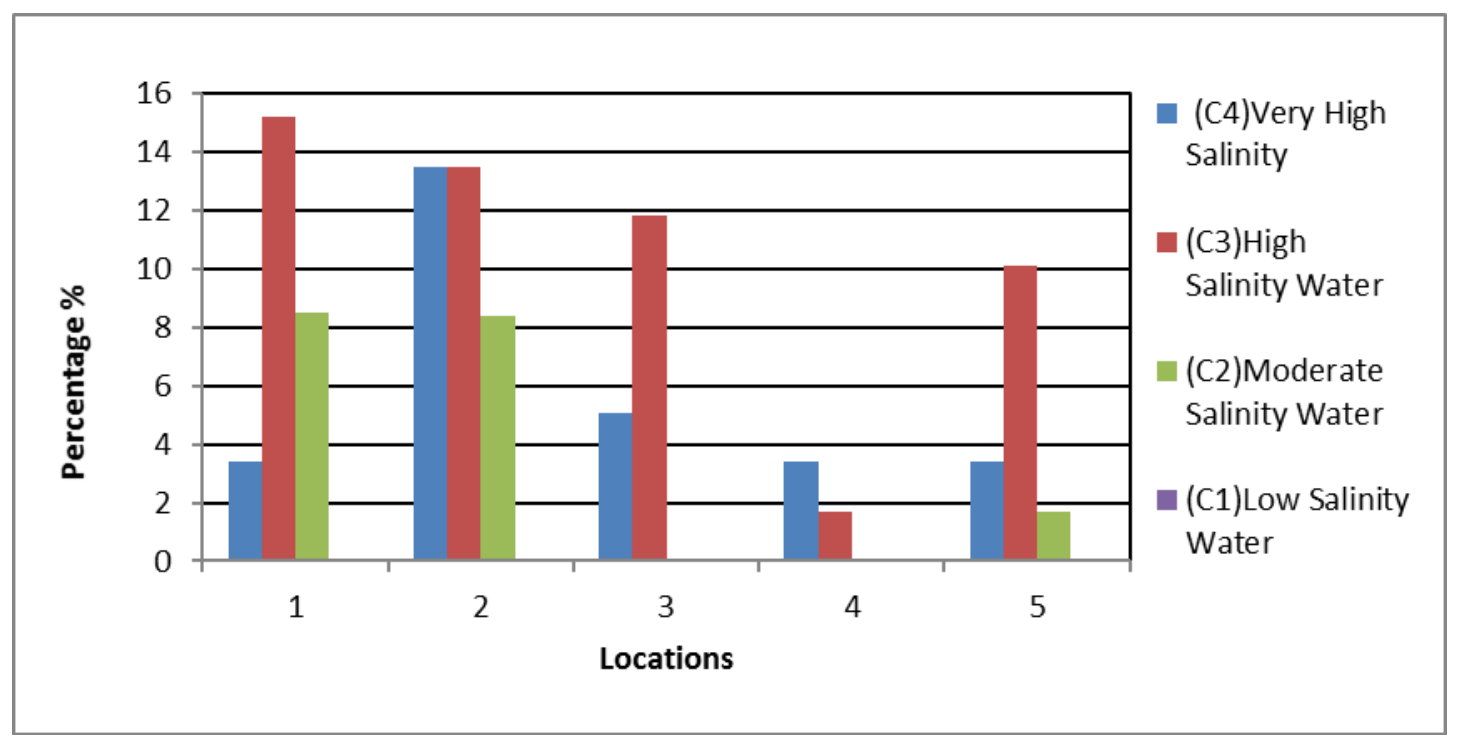

Figure 1. Status of salinity in irrigation water of Hail region. 
The sodium ion concentrations ranged from 0.74 to

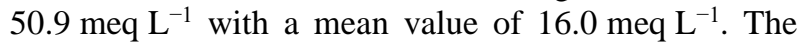
main reasons for the increase in $\mathrm{Na}^{+}$level in groundwater are the cation exchange through waterrock interaction supported by human activities (Ramkumar et al., 2013).

The sodium/alkali hazard is expressed as the sodium adsorption ratio (SAR). This index quantifies the proportion of sodium to calcium and to magnesium ions in a sample. The sodium hazard of water can be properly predicted by determining the SAR. SAR values were calculated following to $\mathrm{SAR}=\mathrm{Na} /(\mathrm{Ca}+\mathrm{Mg}) 0.5$ (Richard, 1954). Table 2 shows that there is no sodicity problem in all locations (all water samples had SAR values of less than 9) excluding one sample in location 4 which had a severe sodicity problem (SAR > 9).

\section{Total Alkalinity, Bicarbonates, and Carbonates}

Alkalinity is a measure of the dissolved materials in water that can buffer or neutralize acids. These include carbonates $\left(\mathrm{CO}_{3}^{--}\right)$, bicarbonates $\left(\mathrm{HCO}_{3}{ }^{-}\right)$, and hydroxides $\left(\mathrm{OH}^{-}\right.$, rarely present in that form).

The concentration of bicarbonate $\left(\mathrm{CO}_{3}^{--}\right)$and carbonate $\left(\mathrm{HCO}_{3}^{-}\right)$in groundwater resulted from the dissolution of carbonate weathering and carbonic acid in the aquifers (Kumar et al., 2009). The observed average value of bicarbonate concentration obtained in Hail was $1.52 \mathrm{meqL}^{-1}$, and ranged between 0.03 and $2.54 \mathrm{meqL}^{-1}$. The carbonate ion was not detected in all water samples (Table 2). Also, the alkalinity ranged between 1.5 and $127 \mathrm{mg} / \mathrm{L}$. Ingram (2014) and Will and Faust(1999) reported that the ideal range for total alkalinity is approximately 30 to $100 \mathrm{mg} / \mathrm{L}$ but levels up to 150 $\mathrm{mg} / \mathrm{L}$ may be suitable for many plants. High alkalinity above $150 \mathrm{mg} / \mathrm{L}$ tends to be problematic because it can result to elevated $\mathrm{pH}$ of the growth media which can cause various nutrient problems (e.g., iron and manganese deficiency, calcium and magnesium imbalance) (Leinauer and Devitt, 2013). Consequently, bicarbonate values were in the safe and normal range.

\section{Chloride}

In Hail groundwater, the order of abundance of the major anions was as follows: $\mathrm{Cl}^{-}>\mathrm{HCO}_{3}{ }^{-}>\mathrm{CO}_{3}^{--}$. A similar trend was found by Tanvir et al. (2017).

Chlorides are leached from various rocks into the soil and water by weathering. The chloride ion is highly mobile and is transported to closed basins or oceans (WHO, 1996). Chloride behaves as a conservative ion in most aqueous environments, meaning its movement is not retarded by the interaction of water with soils, sediments, and rocks. Therefore, chlorides were common of natural water. As expected, the trend of chloride distribution follows the water salinity trend. The observed average value of chloride concentration obtained in Hail was $15.5 \mathrm{meq} \mathrm{L}^{-1}$, and ranged between 0.65 and $48.5 \mathrm{meqL}^{-1}$ (Table 2). In fact, $31.1 \%$ in Hail groundwater samples have the potential risk of chloride hazard (chloride > $10 \mathrm{meq} \mathrm{L^{-1 }}$ ) (Ayers and Westcot, 1985).

According to Palacios et al. (1997) the effect of chloride concentration on usable water in cultivation was analyzed. The degrees of restriction for irrigation water samples are presented in Table 3 . The degree of ion chloride restriction $\left(\mathrm{Cl}^{-}\right)$in irrigation water with concentrations lower than 4 meq $\mathrm{L}^{-1}$ is considered light (13.3\%), between 4 and 10 meq $\mathrm{L}^{-1}$ is moderate (55.7\%), and concentrations higher than $10 \mathrm{meq} \mathrm{L}^{-1}$ are considered severe $(24.5 \%)$. The maximum limit is 30 meq $\mathrm{L}^{-1}(6.5 \%)$.

\section{Heavy metals}

Heavy metals are the one of the most important pollutants and when entering the food chains they can cause serious problems to human health (Mkude, 2015). Table 4 presents the descriptive statistical data. The order of metal levels in groundwater of Hail was as follows: $\mathrm{Pb}>\mathrm{Zn}>\mathrm{Cu}>\mathrm{Ni}$. The concentrations of $\mathrm{Pb}$, $\mathrm{Zn}, \mathrm{Cu}$ and $\mathrm{Ni}$ concentrations ranged from 1.29 to 94.5 , 1.05 to $63.3,1.98$ to 83.8 and 0.75 to $9.21 \mu \mathrm{g} \mathrm{L}^{-1}$, respectively. The highest heavy metals concentrations were obtained in location 4 . The results concluded that in all areas, heavy metals in groundwater were within the acceptable levels, according to Ayers and Wesotcot (1985).

Table 5 showed the correlation coefficients between some chemical properties of groundwater and groundwater EC. Groundwater EC correlated positively with $\mathrm{Cl}, \mathrm{Mg}, \mathrm{Ca}$ and $\mathrm{Na}$ at a significance level of $1 \%$.

$\mathrm{EC}(\mathrm{dS} / \mathrm{m})$ is correlated with $\mathrm{Cl}, \mathrm{Na}^{+}, \mathrm{K}^{+}$, and SAR (ranges from 0. 985 to 0.585 ) while EC is poorly correlated with $\mathrm{pH}$. $\mathrm{pH}$ is poorly negatively correlated with $\mathrm{EC}, \mathrm{Na}^{+}, \mathrm{K}^{+}, \mathrm{Ca}^{+2} \mathrm{Mg}^{+2}, \mathrm{Cl}^{-}$, and $\mathrm{HCO}_{3}^{-}$(ranges from -0.323 to -0.05$)$. This result coincides with the study of Bodrud-Doza et al. (2016). A highly positive correlation was observed between $\mathrm{Cl}$ and $\mathrm{Mg}, \mathrm{Ca}, \mathrm{Na}$ and $\mathrm{HCO}_{3}{ }^{-}$. A similar relation was observed between $\mathrm{Mg}$ and $\mathrm{Ca}, \mathrm{Na}$ and $\mathrm{HCO}_{3}{ }^{-}$. Calcium was highly positively correlated with both $\mathrm{Na}$ and $\mathrm{HCO}_{3}{ }^{-}$. Sodium was highly positively correlated with $\mathrm{HCO}_{3}{ }^{-}$. Similar results were obtained by Ashiyani et al. (2015). 
Table 3. Status of chloride in water irrigation of the Hail region.

\begin{tabular}{lcccc}
\hline The degree of ion chloride restriction & Light & Moderate & Severe & The maximum limit \\
\hline Approx. water chloride, meq L & -1 & $4-10$ & $10-30$ & $>30$ \\
Location 1 & 5.0 & 9.0 & 2.0 & - \\
Location 2 & - & 11.0 & 10.0 & - \\
Location 3 & - & 9.0 & 2.0 & 1.0 \\
Location 4 & - & 1.0 & - & 2.0 \\
Location 5 & 3.0 & 4.0 & 1.0 & 1.0 \\
Total(samples) & 8.0 & 34 & 15.0 & 4.0 \\
\hline
\end{tabular}

Table 4. Descriptive statistics of the heavy metals $\left(\mathrm{ug}^{-1}\right)$ of groundwater from Hail region.

\begin{tabular}{llcccc}
\hline L. & & $\mathbf{Z n}$ & $\mathbf{C u}$ & $\mathbf{N i}$ & $\mathbf{P b}$ \\
\hline L1 & Mini. & 4.7 & 4.33 & 1.98 & 3.83 \\
& Maxi. & 33 & 51.3 & 6.95 & 78.4 \\
L2 & Mean & 17.3 & 16.9 & 3.7 & 25.8 \\
& Mini. & 1.05 & 4.76 & 0.75 & 2.87 \\
& Maxi. & 3.57 & 35.8 & 31.1 & 54.9 \\
L3 & Mean & 17.7 & 24.3 & 6.04 & 20.8 \\
& Mini. & 1.07 & 1.98 & 0.95 & 1.53 \\
& Maxi. & 25.1 & 41.6 & 7.44 & 34.2 \\
L4 & Mean & 12.9 & 18.1 & 4.7 & 13.7 \\
& Mini. & 11.9 & 12.4 & 1.59 & 11.8 \\
& Maxi. & 60.4 & 83.8 & 9.21 & 94.5 \\
L5 & Mean & $35 ; 5$ & 46.5 & 6.68 & 50.9 \\
& Mini. & 12.1 & 11.7 & 1.27 & 1.29 \\
Acceptable levels & Maxi. & 63.3 & 33.1 & 8.33 & 78.1 \\
\hline
\end{tabular}

L: Location, Mini: Minimum, Maxi: Maximum. Acceptable levels according to (Ayers and Westcot, 1985).

Table 5. Simple correlation between EC and chemical properties.

\begin{tabular}{lccccccc}
\hline & $\mathbf{E C}$ & $\mathbf{C l}$ & $\mathbf{K}$ & $\mathbf{M g}$ & $\mathbf{C a}$ & $\mathbf{N a}$ & $\mathbf{H C O}^{-}$ \\
\hline $\mathrm{Cl}$ & 0.976 & & & & & & \\
$\mathrm{~K}$ & 0.595 & 0.511 & & & & & \\
$\mathrm{Mg}$ & 0.966 & 0.960 & 0.567 & & & & \\
$\mathrm{Ca}$ & 0.976 & 0.941 & 0.572 & 0.914 & & & \\
$\mathrm{Na}$ & 0.985 & 0.953 & 0.636 & 0.950 & 0.947 & & \\
$\mathrm{HCO}_{3}{ }^{-}$ & 0.0 .00 & 0.976 & 0.596 & 0.966 & 0.976 & 0.985 & -0.323 \\
$\mathrm{pH}$ & -0.322 & -0.285 & -0.050 & -0.303 & -0.321 & -0.280 & \\
\hline
\end{tabular}

*Significant correlation between EC \& TDS, EC \& Salinity, TDS \& Salinity, TDS \& Turbidity, TH \& Chloride 


\section{CONCLUSION}

The quality of groundwater resources in the selected Hail regions indicated that the groundwater salinity for irrigation was relatively high in most studied water samples, and the EC values ranged from 0.27 to $8.99 \mathrm{dS}$ $\mathrm{m}^{-1}$ in the study area. The lowest value was found in location 5, and the highest was found in location 4 . However, pH values, SAR and heavy metals in groundwater in all areas were within acceptable levels.

\section{ACKNOWLEDGMENT}

The authors wish to acknowledge the financial support provided by the Chair of Sustainable Development in Agricultural Communities in the University of Hail.

\section{REFERENCES}

Abdel-Aal, S.I., R.E. Sabrah, R.K. Rabie and H.M. AbdelMagid .1997. Evaluation of groundwater quality of irrigationin central Saudi Arabia, Arab Gulf. J. of Scientific Research, 15: 361-377

Alawi, J., and M. Abdulrazzak. 1993. Water in the Arabian Peninsula: Problems and Prospective. In Water in theArab World Perspectives and Prognoses (Rogers P, Lydon P, eds). Harvard University. USA:171-202

Al-Omran, A.M. 2002. Irrigation water conservation in Saudi Arabia. J. of the Saudi Society of Agricultural Sciences, 1(1): $1-50$

Al-Salamah, I.S., Y.M. Ghazaw and A.R. Ghumman. 2011. Groundwater modeling of Saq Aquifer in Buraydah, AlQassim for better water management strategies. Environ. Monit. Assess. 173: 851-860

Ashiyani, N., F. Parekh and T.M.V. Suryanarayana.2015. Analysis of physico-chemical properties of groundwater. International Journal of Innovative Research in Science,Engineering and Technology. 4. 3: 1094-1098

Ayers, A.S. and D.W. Westcot.1985. Water Quality for Agriculture. Irrigation and Drainage Paper 29 (Rev.1). FAO,Rome, Italy.

Bodrud-Doza, M.D., A.R.M. Towfiqullslam, F. Ahmed, SamiranDas, NarottamSaha and S.M. Rahman. 2016. Characterization of groundwater quality using water evaluation indices, multivariate statistics and geostatistics in central Bangladesh.Water Science. 30 1: 19-40

Duncan, R. R., R. N. Carrow and M. T. Huck. 2009. Turfgrass and landscape irrigation water quality: Assessment and management. CRC Press. Taylor \& Francis Group. Boca Raton, FL.

Hem, J.D. 1985 Study and interpretation of the chemical characteristics of natural water Vol. 2254. Department of the Interior, US Geological Survey.
Hereher, M.E., A.M., Al-Shammari and S.E. Abd Allah. 2012. Land cover classification of Hail-Saudi Arabia using remote sensing. Int. J. Geosci. 3: 349-356

Hillel, D. 2000. Salinity management for sustainable irrigation: Integrating science, environment, and economics. The International Bank for Reconstruction and Development/The World Bank. http://dx.doi.org/10.1596/0-8213-4773-X.

Ingram, D. 2014.Understanding Irrigation Water Test Results and Their Implications on Nursery and Greenhouse Crop Management, University of Kentucky Cooperative Extension Service, Publication HO-111

Jackson, M.L. 1967. Soil Chemical Analysis. Prentice-Hall, Inc., Englewood Cliffs, USA.

Kumar, S. K., S. H. Babu, P. Rao, S. E.Selvakumar, C. Thivya, S. Muralidharan and G. Jeyabal. 2017. Evaluation of water quality and hydrogeochemistry of surfaceand groundwater, Tiruvallur District, Tamil Nadu, India. Appl. Water Sci. 7:2533-2544

Kumar, S.K., V. Rammohan, J.D. Sahayam and M. Jeevanandam. 2009. Assessment of groundwater quality and hydrogeochemistry of Manimuktha River basin, Tamil Nadu, India. Environ. Monit. Assess., 159 : 341351

Kumaresan, M. and P. Riyazuddin. 2006. Major ion chemistry of environmental samples around sub-urban of Chennai city. Current Sci.91(12): 1668-1677

Leinauer, B. and D. A. Devitt. 2013. Irrigation science and technology In: Turfgrass: biology, use, and management. Agronomy Monograph No. 56. Eds. J.C. Stier, B.P.Horgan, and S.A. Bonos. ASA-SSSA-CSSSA. Madison, WI.

Mkude, I.T. 2015. Comparative analysis of heavy metals from groundwater sources situated in Keko and Kigogo residential areas, Dar es Salaam. J. Water Resour. Ocean Sci. 4 (1): 1-5

Mohammed A., T. Georg, S. Christoph and R. Randolf. 2011. Challenges for an Integrated Groundwater Management in the Kingdom of Saudi Arabia. International J. of Water Resources and Arid Environments, 1(1): 65-70

Oster, J.D. and N.S. Jayawardane. 1998. Agriculture management of sodic soils. In Sodic Soils: Distribution, Process, Management andEnvironmental Consequences (Eds. M.E. Summer and R. Naidu), Chapter 8, pp. 125147. Oxford Univ. Press, UK.

Palacios, V., E.J. Chávez, and L. Tijerina. 1997. Requerimientos de aguaparariego. In: Requerimientos de aguaparariego del Manual Nacional de Ingeniería del Serviciode Conser- vación de Suelos. Departamento de Agricultura de losEstadosUnidos de América. ComisiónNacional del Agua. Edo de México, México. $405 \mathrm{pp}$.

Panno, S.V., V. Nuzzo, K. Cartwright, B.R. Hensel and I.G. Krapac. 1999. Changes to the chemical composition of groundwater in a fen-wetland complex caused by urban development. Wetlands 19 (1) :236-245 
Ramkumar, T. S. Venkatramanan, I. Anithamary and S.M.S. Ibrahim. 2013. Evaluation of hydrogeochemical parameters and quality assessment of the groundwater in Kottur blocks, Tiruvarur district, Tamilnadu, India. Arab. J. Geosci., 6. pp: 101-108

Rhoades, J.D., A. Kandiah and A.M. Mashali. 1992. The use of saline waters for crop production-FAO irrigation and drainage paper 48. FAO, Rome, 133.

Richard, L.A. 1954. Diagnosis and Improvement of Saline and Alkali Soils. Agricultural Handbook 60. USDA, Washington, USA

Sharaf, M.A., and M.T. Hussein. 1996. Groundwater quality in the Saq aquifer, Saudi Arabia.Hydrological Sci. J. 41: 5: 683-696
SheikhyNarany, T., M.F. Ramli, A.Z.Aris, W.N.A. Sulaiman, H. Juahir and K. Fakharian. 2014. Identification of the hydrogeochemical processes in groundwater using classic integrated geochemical methods and geostatistical techniques, in amol-babol plain, Iran. Sci World J.1-15. doi:10.1155/2014/419058

Tanvir Rahman, M. A. T. M., A. H. M. Saadat, M. S. Islam, M. Al-Mnsur and S. Ahmed. 2017. Groundwater characterization and selection of suitable water type for irrigation in the western region of Bangladesh.7.1 : 233243.

Toumi, N., B.H. Hussein, S. Rafrafi and N. El Kassas. 2015. Groundwater quality and hydrochemical properties of AlUla Region, Saudi Arabia Environ. Monit. Assess., 187 (3). p: 84

WHO. 1996.Guidelines for drinking-water quality, 2nd ed. Vol. 2. Health criteria and other supporting information, World Health Organization, Geneva.

Will, Elizabeth and J. Faust. 1999. Irrigation Water Quality for Greenhouse Production, University of Tennessee Cooperative Extension, Publication PB 1617.

\section{الملخص العربي \\ تقييم جودة المياه الجوفية للزراعة بمنطقة حائل بالمملكة العربية السعودية

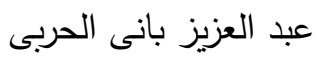

بيكربونات (

والعناصر التثيلة لتقييم مدى ملاعمة المياه الجوفية

V.I. تلأغراض الزراعية. كانت قيم الـ PH

و N. N وتراوحت ملوحة المياه الجوفية كمؤشر أولي لنوعية

المياه لأغراض الري بين متوسطة وعالية في معظم عينات

المياه المدروسة. وإلى جانب الملوحة، فإن \% 1. إب من

عينات المياه الجوفية في حائل لديها مخاطر محتملة لخطر

الكلوريد (كلوريد > • ا ملليمكافئ فى اللتر). كانت قيم SAR

أقل من 9 لجميع عينات المياه الجوفية بينما كانت المعادن

$$
\text { الثقيلة فى حدود المستويات المقبولة. }
$$

نتيجة للمناخ الجاف في المملكة العربية السعودية، تعد

المياه الجوفية أثثن مورد طبيعي، حيث توفرامدادات مياه

موثوقة للسكان المقيمين وتطور الزراعة المروية حيث موارد المياه السطحية غير كافية وقليلة لتلبية متطلبات الميزانية المائية للمملكة المملكة العربية السعودية. لذلك أجريت هذه الدراسة لتقييم جودة موارد المياه الجوفية في مواقع مختارة من منطقة حائل. ركزت هذه الدراسة على التحليل الكيميائي الهام لموارد المياه الجوفية المتاحة في منطقة حائل. تم جمع عينات المياه الجوفية من الج بئراً في مواقع مختلفة تغطي

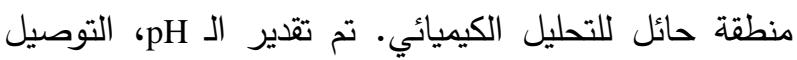
الكهربائى (EC)، الصوديوم (

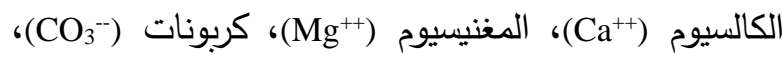

